\title{
REGRESSION APPROACH TO CALCULATE THE EFFECTIVE MUD ANNULAR VISCOSITY DURING DRILLING OIL WELLS
}

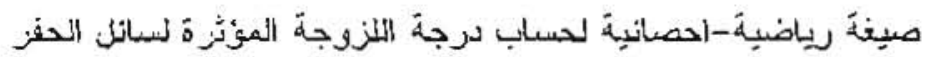

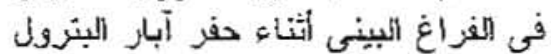

\section{Dr. Mohamed Shebata Farahat}

Suez Canal University, Faculty of Petroleum and Mining Engineening-Suez, Egypt.

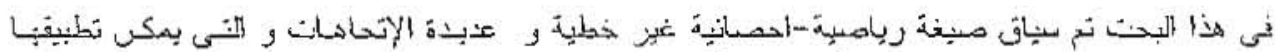

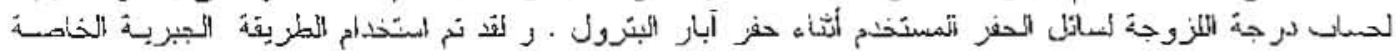
(Rayleigh)

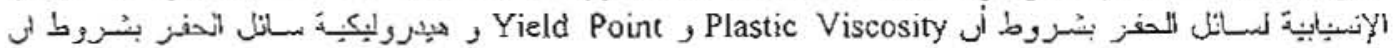

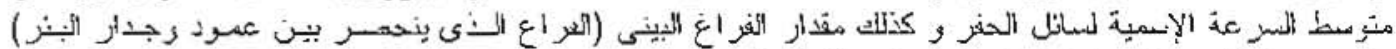

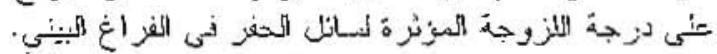

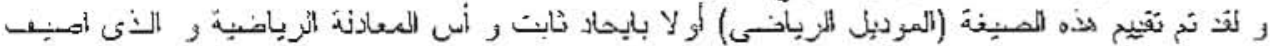

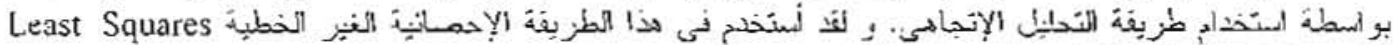

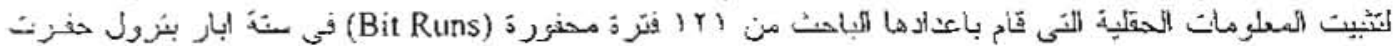

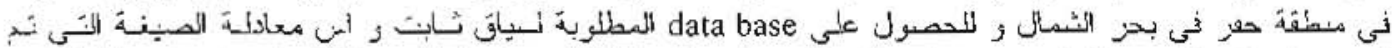

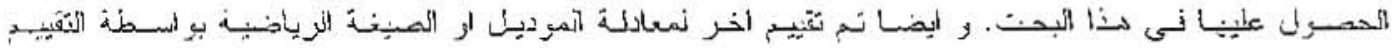

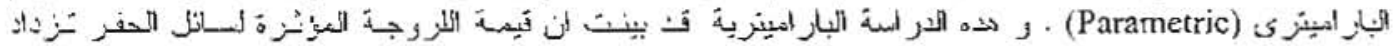

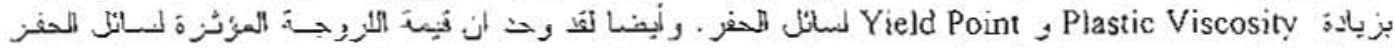

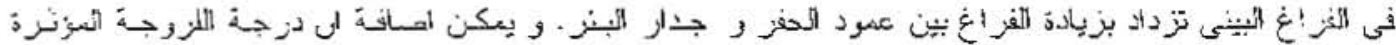

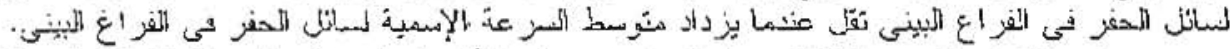

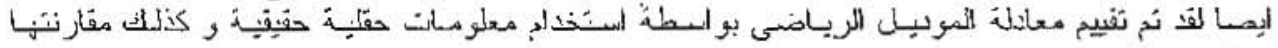

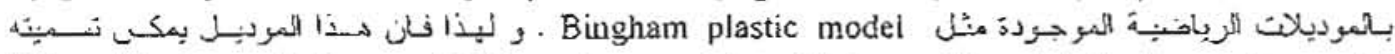
liby. Bingham plastic model, Power-law model, and Polynomial model en Regression model

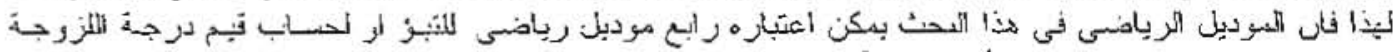

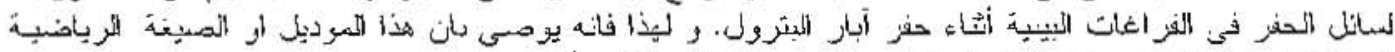

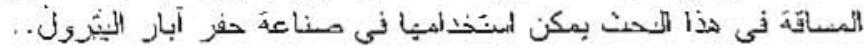

\section{ABSTRACT}

In this paper, a non-linear multidimensional. dimensionless mathematicat drilling mud annular viscosity approach for oil well drilling applications, consisting of one equation, was developed. 
This utilizes the Rayleigh algebraic method for dimensional analysis. Also. this approach reflects the effects of mud rheological properties in terms of plastic viscosity and yield point; mud hydraulics in terms of the nominal average velocity of that mud; and geometry of the well-bore annulus on the effective mud viscosity in the annulus.

This approach was evaluated by first deriving the unknown proportionality constant and one exponent added by dimensional analysis technique. This utilizes the statistical regressional curve of the !east-squares fitting method and using the prepared input field data by the author from 121 arilied intervals in six wells in the North Sea driling region, so as to provide data base required to derive the approach's equation constant and its exponent. A further evaluation of the approach was involved parametrically. This parametric study shows that the effective raud annular viscosity increases when the yield point and plastic viscosity of that mud increase. Also, it was found that the mud anular viscosity increases as the annular space between the wall of hole and drill-pipe increases. In addition, the mud annular viscosity decreases when the nominal average velociry of drilling mud increases.

Also, the approach's equation was verified using actual field data and was compared with existing models such as Bingham piastic model. Thus, this approach may be called as "Regression Model" similar to Bingham plastic model. Power-law model, and Polynomial model. Accordingly, this approach is considered as the fourth model for predicting the values of viscosity of drilling fluid in the annuli of well-bores during drilling. Thus, it was concluded that the approach's predictions were more realistic and reasonable which may give a recommendation that the approach could be used by the oil-well drilling industry.

\section{NTRODUCTION}

The ratio of shear stress to shear rate is the viscosily. The shear stress-shear rate behavior of a Newtonian fluid car be determined by measuring the shear stress at one shear rate. Water for example will have a viscosity of $1.0 \mathrm{cps}$ in the drill-pipe, through the bit nozzles, in the annulus and un the mud tanks. Conversely, the viscosity of a non-Newtonian fiuid varies with shear rates. This means that it is impossible to define a viscosity of a non-Newtonian fluid without specifying a shear rate. Under pumping conditions, an example of a non-Newtonian drilling fluid might have the following viscosities: $20 \mathrm{cps}$ inside the drill-pipe, $3 \mathrm{cps}$ at the bit nozzles, $50 \mathrm{cps}$ opposite the drill collars, $120 \mathrm{cps}$ opposite the drill-pipe and $1200 \mathrm{cps}$ in the mud tanks. That is the reason why the minimum mud rheological/hydraulics program must be flexible during drilling out of gauge sections, so as to avoid the hole clearing problems. Thus, the rheological properties and'or pump rate can be raised without over stressing the well-bore and leaving up the hole around the drill collars. In other words, when drilling in areas where relatively old, dry sloughing shale is a problem.

Thus, the basic objectives of a theology/hydraulics program should be to reduce annular pressure losses and ensure lammar flow by minimizing oversized drill collars and stabilizing equipment. Also, by the use of very non-Newronian low-solids drilling fluids, minimum bit nozzles viscosities can be obtained with maximum effective mud annular viscosities for hoie cleaning. Mud flow properties and/or pump rates can be adjusted to keep the adequate hole cleaning. 
Accordingly, it is necessary to raise the viscosity of the driiling fluid by increasing the yield point or ratio of yield point to plastic viscosity which are considered the most significant rheological propenies of the drilling fluio. that affect the cleaning-up of the bit cuttings and cavings from the hole during drilling. Field experience indicated that during very fast upper-hole drilling or soft formation dirilling, raising mud viscosity, or annular mud viscosities considerably in excess of the maxinum siip velocity of drilled-cuttings or cavings are necessary to prevent balling the bit and drill coilars. These variations in drilling fluid properties and circuiation rates of that fluid are required to ensure adequate hole cleaning during drilling.

Because this effective mud annular viscosity is dependent on the velocity of the mud and the pattern of flow, whether laminar or turbulent, this viscosity is difficult to measure. in oil-wetl drilling engineering only changes in the annular viscosity are of great concern to the drilling engineer, as such changes directly affect cuttings removal (hole cleaning) and annular pressure losses, which in turn affect the actual bortom-hole pressure of circulating drilling fluid. in practice, three models $[1,2]$ are used to describe the flow of non-Newtonian fluids which form the most of ci.illing fluids, these models are:

1. Bingham plastic model: $\tau=A+B Y$

2. Power-Law modei: $\quad \tau=\ln Y^{\mathrm{N}}$

3. Polynomial model: $\quad \tau=\mathrm{A}+\mathrm{BY}+\mathrm{CY} Y^{3}+\mathrm{EY}^{5}+\ldots$. .

But in oil-well drilling industry, two models $[3.4]$ are only used to describe the flow behavior of drilling fluids; the Bingham plastic model and Power-Law model.

The objective of this paper was to develop a field-oriented regression effective mud annular viscosity approach for oil-well drilling applications, in order to design optimum dniling operations with adequate hole cleaning. In tum, an increase in drilling rate is obtained at the lowest possible drilling coast. This study was planned due to the inaccuracies of both Bingham plastic model and Power-Law model predictions at the lower shear rate ranges. However. this regression approach or the proposed mud rheological model provides more consistently accurate descriptions of the theology of non-Newtonian fluids (drilling Aluids) used during drilling oilwells. In other word, this iegression approach may improve the predictions accuracy of effective mud annular viscosities more than the Bingham plastic model and Power-Law model predictions. This was due to the mathernatical formulation of the regression approach, that was generated from the fitting actual field data by statistical regression analysis which gives more precise constants for this approach more the constants of both Binghand plastic and Power-Law models.

Therefore, this study was planned to investigate the most significant factors which affect the pinysical situation of effective mud annular. viscosity predictions. The factors under study were generally classified into the following:

A. Rheological properties of drilling fluid in terms of:

1. Plastic viscosity.

2. Yield point.

B. Drilling fiuid hydraulics in terms of the nominal average velocity of that fluid in the annulus.

C. Well-bore annuius geometry in terms of the annular space between the drill-pipe and the wall of the hole. 
Then, applying the Rayleigh alyebraic method of dimensional analysis to dievelop a mathematical formula which relates the effective mud annular viscosity parameter with the above-mentioned factors (independent parameters). To determine the unknown constant and one exponent added by dimensional analysis technique, this can be determined by the best fitting curve through the prepared field data by the author from 121 drilled incervals in six wells in the Nortin Sea drilling region. The developed regression approach of effective unud annular viscosity was evaluated parametrically by applying the partial differentiation principies, so as 10 investigate the effect of changing one of the following : yield point, plastic viscosity, nomiral average velocity of drilling fluid in the annulus and amular space on the effective viscosity of that Huid in the annulus during drilling

Finally, to determine the validity and generality of the developed regression approach for application in oil-well drilling industry, the approach's equation was verified using actual field data and was compared with existing models such as Bingham plasuc model.

\section{MATHEMATICAL FORMULATION OF EFFECTIVE MUD ANNULAR VISCOSITY APPROACH}

The effective anumar viscosity of dritling thuid is defined as the viscosity ol drilling fluid which surrouts the drilleci-cutungs in the annulus without consideration of the shear thinning of doilting fluid, which is caused by the drill-pipe rotation during drilling. Perinaps this condition represents the drilling process with using "drilling downhole motors " where no rotation for drill-pipe during drilling operations. The study of the effect of driil-pipe rotatron on mud annular viscostiy nay complicate the problem. thereforc. this effect is neglected tor saking the simplicity of the problem. It was found that $|\lambda-4|$ the eftective viscosity of the drilling fluid in the annulus during dritling depends on the tollowing parameters:

A. Physical or tow properties of drilling liud in terms of rheological propertics of that fluid, namely:

1. Plastic viscosity, $\mu_{\mathrm{p}}$.

2. Yield point. Yp.

$B$. The hydaulic effect of drilling tlaid in terms of the nominal average veloctiy of that fluid in the annulus, $V_{\mathrm{m}}$.

C. Geometry of the well-bore annulus in terms of the annular space between the drill-pipe and the wasl of the hols, $\mathrm{D}_{\mathrm{H}}-\mathrm{D}_{\mathrm{p}}$.

Thus. the physıcal relationship between effective annular viscosity of ciriling fluid and the above-mentioned parameters can be expressed as follows:

$$
\mu_{e}=f\left(\mu_{p}, Y_{p}, V_{m}, D_{1}-D_{p}\right)
$$

Mathematically, Equ. (1) cau be equated to zero by incituding the dependient parancter, $\mu_{\mathrm{c}}$, as independent parameter.

Therefore,

$$
f\left(\mu_{e}, \mu_{p}, Y_{p}, V_{m}, D_{H}-D_{p}\right)=0
$$


Applying the Rayleigh method of dimensional analysis [5,6], each parameter can be raised to an exponent. Therefore, Equ. (2) becomes:

$$
f\left(\left(\mu_{e}\right)^{a},\left(\mu_{p}\right)^{b},\left(Y_{p}\right)^{c},\left(V_{r q}\right)^{d},\left(D_{H}-D_{p}\right)^{e}\right)=0
$$

Equ. (3) may be expressed in terms of its dimensions for each parameter in the $M$, $L$, and $T$ system as follows:

$$
f\left(\left(M^{-1} T^{-1}\right)^{a},\left(M L^{-1} T^{-1}\right)^{b} \cdot\left(M L^{-1} T^{-2}\right) c,\left(L T^{-1}\right)^{d} \cdot(L)^{e}\right)=M^{0} L^{0} T^{0}
$$

In Equ. (4), the right hand side has zero exponents. equating the powers of $\mathrm{M}$, $\mathrm{L}$, and $\mathrm{T}$. Therefore,

$$
\begin{array}{ll}
\sum_{i}^{3} M=0, & \text { then, } a+b+c=0 \\
\sum_{L}^{5} L=0, & \text { then, }-a-b-c+d+e=0 \\
4 & \\
\sum_{l} T=0 . & \text { then, }-a-b-2 c-d=0
\end{array}
$$

To derive the required expression, it may be noted that the variables appearing more than once in it. Hence, eliminate $b$ and $e$. This gives the following:

$$
\begin{aligned}
& b=-a-c \\
& e=a+b+c-d
\end{aligned}
$$

Substituting the value of b from Equ. (8) into Equ. (9), Equ. (9) gives:

$$
e=-d
$$

Substituting the value of $b$ and $d$ in Equ. (4), Equ. (4) becomes:

$$
f\left(\left(M L^{-1} T^{-1}\right)^{a},\left(M L^{-1} T^{-1}\right)^{-a-c} \cdot\left(M L^{-1} T^{-2}\right)^{c} \cdot\left(L T^{-1}\right)^{d},(L)^{-d}\right)=M^{0} L^{0} T^{0}
$$

Now, collecting the terms rassed to remaining powers, thus:

$$
\left[\left[\frac{\mu_{p}}{\mu_{p}}\right]^{s}\left[\frac{\mathrm{Y}_{p}}{\mu_{p}}\right]^{s}\left[\frac{\mathrm{V}_{m}}{\mathrm{D}_{\mu}-\mathrm{D}_{\mathrm{p}}}\right]^{\mathrm{d}}\right]=0
$$

Therefore, the appropriate expression obtained by the Rayleigh algebraic method for solving this problem is given as : 


$$
\phi\left[\frac{\mu_{s}}{\mu_{P}}, \frac{\mathrm{Y}_{\mathrm{p}}}{\mu_{Q}}, \frac{\mathrm{D}_{\varphi}-\mathrm{D}_{0}}{\mathrm{~V}_{\mathrm{m}}}\right]=0
$$

Moving the independent parameter $\mu_{e}$ as original parameter (dependent paraneter) with its dimensioniess group to the right hand side and form remaining expression. Then, renanung the exponents and adding a proporionality coustant to the renaming expression. Equ. $(13)$ becomes :

$$
\frac{u_{p}}{\mu,}=\mathrm{c}\left[\frac{Y_{p}}{u_{p}} \frac{D_{H} \cdot D_{p}}{V_{n}}\right]^{n}
$$

where

$$
\left[\frac{Y_{P}}{u_{0}} \frac{D_{M} \cdot D_{2}}{V_{i n}}\right] \text { is dimensioniess group similar to the right hand side. }
$$

$\mathrm{c}$ is proportionality constant added by Rayleigh a!gebraic method of dimensiomal analysis rechnique ior solvung the problem in the final analysis.

n raised exponent by Rayleigh algebraic nethod of dimensional analysis technique to the dimensioniess group.

Eạ!: (14) is the final form of mathematical formulation for the effective annular viscusıty of drilling fluid cluring cirilling oil wells.

\section{LINEAR REGRESSION ANALYYSIS FOR THE MAXHEMATICAX FORIULA OF EFFECTIVE MUO ANNULAR VISCOSITY}

Taking the logarithms of Equ(l4). Thus.

$$
\operatorname{Ln}\left[\frac{u_{c}}{u_{z}}\right]=\operatorname{Lnc}+\mathrm{n} \operatorname{Ln}\left[\frac{\mathrm{Y}_{s}}{\mu_{p}} \frac{\mathrm{D}_{\mathrm{r}}-\mathrm{D}_{\mathrm{p}}}{\mathrm{V}_{m}}\right]
$$

Now. Equ.(14) is an intonsically linear model regression analysis when "Lu c" is the intercept of the firted line by the least- squares method and " $n$ " is the parameter estimate for the indepentlent term included in that equation. Equ.(15) may be simplified as follows:

$$
\operatorname{Ln} A_{1}=\operatorname{Ln} c \div n \operatorname{Ln} A_{2}
$$

where:

$$
A_{1}=\frac{\mu_{\epsilon}}{u_{1}} \quad \mathrm{~A}_{2}=\frac{\mathrm{x}_{0}}{u_{p}} \frac{\mathrm{D}_{\mathrm{H}}-\mathrm{D}_{\mathrm{p}}}{\mathrm{V}_{\mathrm{m}}}
$$

The inpr: *intes of $\operatorname{Ln} A_{1}$ and $\operatorname{Ln} A_{2}$ have been coinputed from the prepared field data which were di is the suthor. 
Regression anaiysis using the statistical Minitab computing system, was applied to regress these input values ( $\operatorname{Ln} A_{1}, \operatorname{Ln} A_{2}$ ), using the following command $[7,8]$ :

Regress $\mathrm{Y}$ in $\mathrm{Cl}$ on I Predictor in $\mathrm{C} 2$.

Where:

$\mathrm{Cl}=$ Column $\mathrm{i}$ contains the input values of $\mathrm{Ln} \mathrm{A}_{1}$.

$\mathrm{C} 2=$ Column 2 contains the input values of $\operatorname{Ln} \mathrm{A}_{2}$.

The regression output was obtained by the author for developing Equation (14). The values of intercept and regression coefficient were rounded off as follows:

$$
\text { Ln } c=5.69200 \cong 5.69 \quad n=0.974567 \cong 0.975
$$

Therefore, the regression equation is:

$$
C_{1}=5.69+0.975 C_{2}
$$

Where

$\mathrm{Lnc}=\mathrm{Ln}$ intercept of best fitted line.

$\operatorname{Ln}=$ natural logarithm .

$\mathrm{n} \quad=$ estimated regression coefficient of $\mathrm{C}_{1}(\mathrm{Y})$ upon $\mathrm{C}_{2}(\mathrm{X})$.

$\mathrm{Y} \quad=$ predicted value of $\mathrm{Ln}\left(\mathrm{H}_{\mathrm{e}} / \mathrm{up}\right.$ ) given by a regression equation.

$\mathrm{X} \quad \mathrm{Ln}$ vaiue of designed dimensionless groun of

$$
\frac{Y_{p}}{\mu_{p}} \frac{D_{n}-D_{0}}{V_{m}}
$$

Substituting the anti-Ln (anti-logarithu) value of the proportionality constant (295.9) and the value of " $n$ " into Equation (14). Therefore,

$$
u_{z}=295.9 \mu_{\mathrm{p}}\left[\frac{\mathrm{Y}_{\mathrm{P}}}{\mu_{\mathrm{p}}} \frac{\mathrm{D}_{\mathrm{H}}-\mathrm{D}_{\mathrm{p}}}{\mathrm{V}_{\mathrm{m}}}\right]^{0.975}
$$

Equation (18) is the regression approach for predicting the effective annular visc - '.' of drilling thid during drilling an oil well.

\section{PARAMETRIC STUDY OF THE REGRESSION APPROACH OF EFFECTIVE ANNULAR MUD VISCOSITX DURING DRULING OLL WELLS}

The resuiting solutions of partial differentiation of Equation (14) for the effective annular viscosity of drilling tluid may be expressed as follows: 


$$
\begin{aligned}
& \frac{\partial \mu_{\mathrm{c}}}{\partial \mathrm{Y}_{p}}=\mu_{\mathrm{c}}\left(\frac{\mathrm{n}}{\mathrm{Y}_{\mathrm{p}}}\right) \\
& \frac{\partial \mu_{\mathrm{c}}}{\partial \mu_{\mathrm{p}}}=\mu_{\mathrm{c}}\left(\frac{1-\mathrm{n}}{\mu_{\mathrm{p}}}\right) \\
& \frac{\partial \mu_{\mathrm{c}}}{\partial\left(\mathrm{D}_{\mathrm{H}}-\mathrm{D}_{\mathrm{p}}\right)}=\mu_{\mathrm{c}}\left(\frac{\mathrm{n}}{\mathrm{D}_{\mathrm{H}}-\mathrm{D}_{p}}\right) \\
& \frac{\partial u_{\mathrm{c}}}{\partial \mathrm{V}_{\mathrm{s}}}=\mu_{\mathrm{e}}\left(\frac{-\mathrm{n}}{\mathrm{V}_{\mathrm{m}}}\right)
\end{aligned}
$$

The lowest and highest values of $Y_{p}, \mu p, D_{H}-D_{p}$ and $V_{m}$ parameters being studied, and the values of $u_{e}$ at minimun and maximum values of parameters under study were prepared by the author. Also, the value of $n=0.975$. Then, the input program of CSMP [9] was run to sinulate the parametric study of $\hat{\partial} \mu_{\mathrm{e}} / \partial \mathrm{Y}_{\mathrm{p}}, \partial \mu_{\mathrm{e}} / \partial \mu_{\mathrm{p}}, \partial \mu_{\mathrm{e}} / \partial \mathrm{V}_{\mathrm{m}}$ and $\partial \mu_{\mathrm{e}} / \partial\left(\mathrm{D}_{\mathrm{H}}-\mathrm{Dp}_{\mathrm{p}}\right)$. The numerical simulation processes from CSMP have been initialized at the minimum values of $Y_{p}, ! l, D_{H^{-}}$ $D p$ and $V_{m}$ parameters, and have been ended at the maximum values of these parameters. The simulation values of parametric study was plotted agaunst the minimum to the maximun values of the above-mentioned parameters. These piots are shown in Figures 1, 2, 3, and 4.

\section{DISCUSSION AND SIGVIFICANCE OF THE PARAMETRIC STUDY OF THE REGRESSION APPROACH FOR " $\mu_{\mathrm{e}} "$}

The simulation results of paranetric study of Equ. (18) of eftective annular viscosity of dritling fluid, are shown in Figures 1, 2, 3, and 4.

Figure 1: is the plot of the partiai derivative of the effective annular viscosity of drilling fluid with respect to the yie!d point of that fluid, versus the yield point. The slope of the associated curve is negatıve, which means that an increase in the effective annular viscosity of drilling fluid when the yield point of the drilling fluid increases during drilling. This result agrees with the Power-law model and Bingham plastic model results [3] and assists the mud engineer to control the yield point of the drilling fluid to obtain the required effective viscosity of that fluid in the annuti of weilbores diuring drilling.

Figure 2: gives the plot of the partiai derivative of the effective annular viscosity of drilling fluid during drilling oil wells with respect to the plastic viscosity of that fluid, versus the plastic viscosity. The associated curve in this plot has a negative slope. which neans that an increase in the effective anular viscosity of drilling fiuid will occur as the plastic viscosity of that fluid increases. Also, this result confirms the Bingham plastic model results [3]. The physical significance of plots 1 and 2 indicates that the yield point of drilling fluid increases the effective annular viscosity of that fluid more than the plastic viscosity of that fluid. Hence, it is 


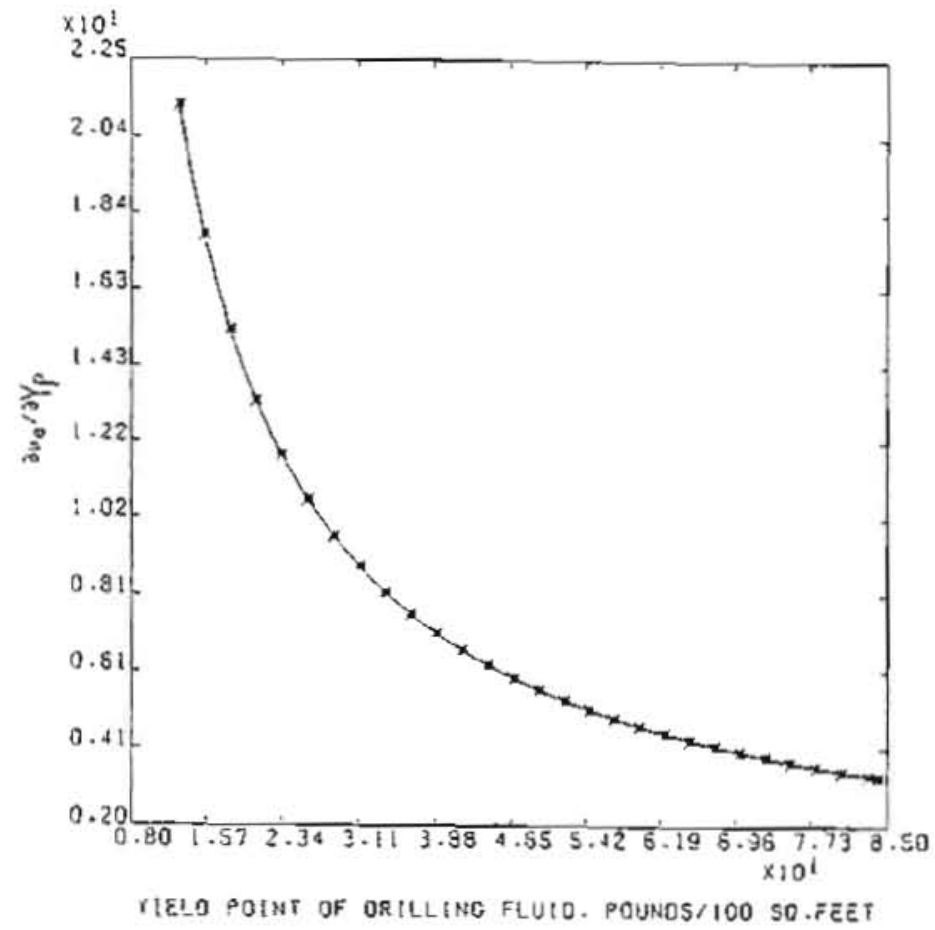

Fig I: $\partial \mu_{\mathrm{e}} / \partial \mathrm{Y}_{\mathrm{p}}$ Versus. Yieid Point of Drilling Fluid.

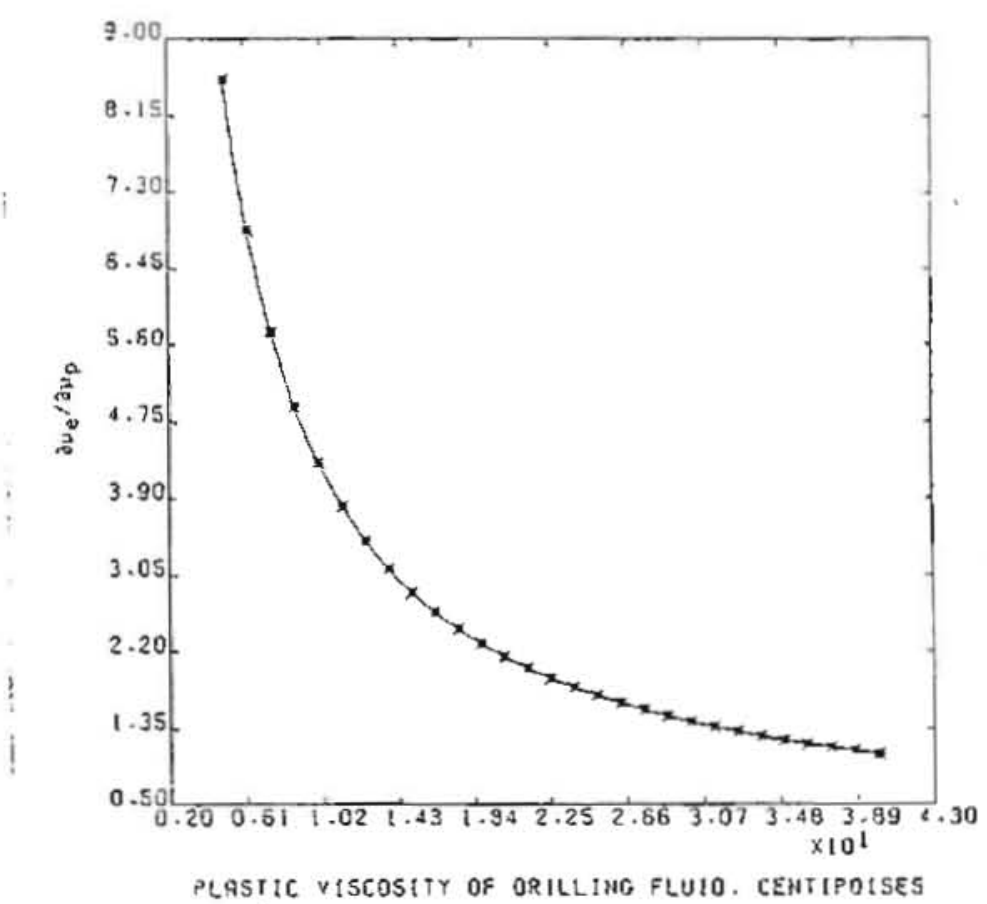

Fig. 2: $\partial \mu_{\mathrm{e}} / \partial \mu_{\mathrm{p}}$ Versus. Plastic Viscosity of Drilling Fluid. 
recommended to use a mud with irverted rheology where the vield point is higher than the plasuc viscosity.

Figure 3: represents the plot of the partial derivative of the effective annular viscosity of driling fluid during brilling oil wells with respect to the annular space between the wall of the hole and the drill-pipe, versus the annular space. This plot shows an increase in the effective annular viscosity of drilling fluid with an increase in the annular space between the wall of the hole and the drill-pipe durng drilling. As the annular space between the wall of the bole and the drill-pipe increases, the annular velocity of drilling fluid decreases at constant circulating flow rate of that fluid. This moves the flow regıme in the annulus to laminar or viscous flow, and the curve shows a continuous increase. This result agrees with the Power-law model and Bingham plastic model resuits $\{3\}$.

Figure 4: is the plot of the partial derivative of the effective annular viscosity of driling fluid with respect to the nominal average veiocity of that fluid in the annulus, versus the nominal average velocity. The resultant slope of the associated curve in this plot is positive. which means that a reduction of the erfectuve annular viscosity of drilling fluid as the nominal average velocity of that fluid in the annuius increases during drilling. Theoretically, the increase in the nominal average velocity of drilling tluid moves the flow regime in the annulus to the turbulent flow. and this is wiby the curve shows a contmuous decrease. However, this resuit confirms the Power-law modei and Bingham plastic model results [3].

From field experience and practices in the North Sea, the Guif of Mexico, and the Guif of Suez. The previous recommendations as to mud type may be developed. A mud with inverted rheology characteristics may be chosen as would a mud such as an "inverted-oil-emulsion" for directional and horizontai drilling. Therefore, inverted-oil-entuision mud is one possible answer to fielddevelopment driling for centrai platforms due to the following reasons. namely:

(a) Reducing the excessive pipe rolating torque and drag.

(b) it has good carrying capacity, i.e. an adequate hole cleaung.

(c) Drilis a gauge hole.

(d) Most cost effective in terms of the mud cost and drilling davs [10\}.

(c) Prevention of differential-pressure sticking whilst driiling potentially under-pressured pemeable pay zone sections. In tum. the permeability damage of pay zone section during drilling can be avorded.

Accordingly, it seems that the inverted-oil-emulsion mud is very useful during drilling pay zone sections or deep drilling operations of directional wells or horizontal drilling section in thin pay zones.

\section{VERLICATION OF REGRESSION APPROACH FOR " $\mu_{\mathrm{e}}$ "}

The deveioped regression approach for predicting the effective annular viscosity of drilling fluids given by Equ. (1S), where $V_{m}$ is given by the following equation:

$$
V_{* *}=\frac{Q_{m}}{A_{3}}
$$




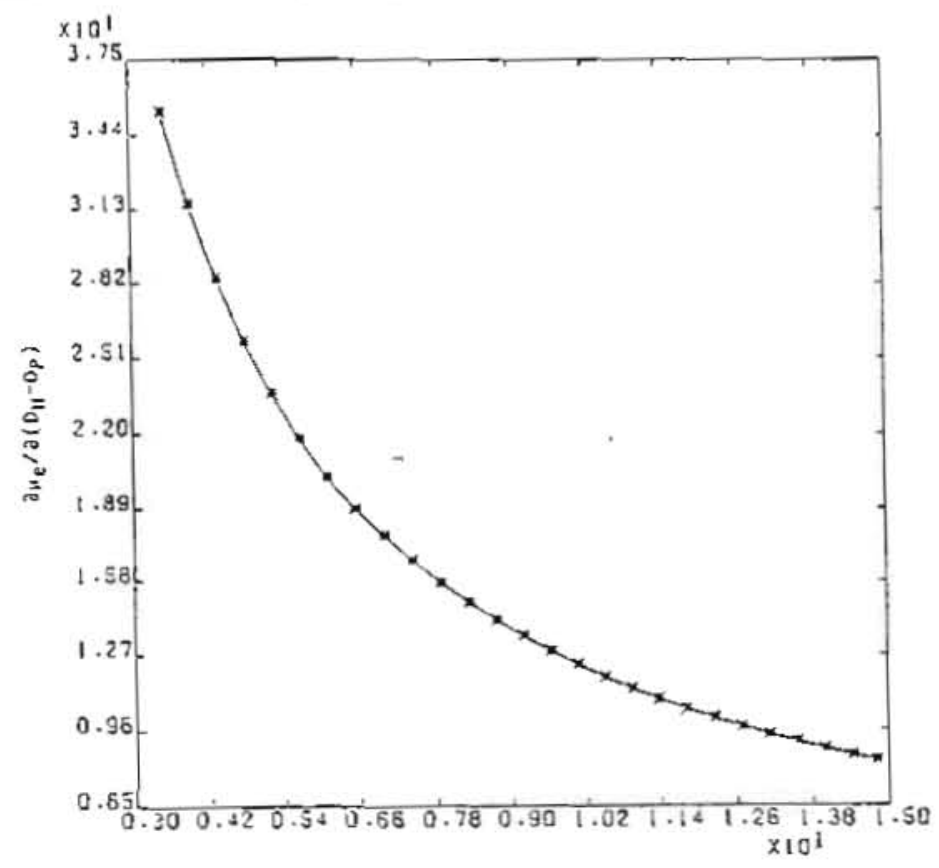

GNMULAR SPACE. INCHES

Fig. 3: $\partial \mathrm{He}_{\mathrm{e}} / \partial\left(D_{\mathrm{H}}-\mathrm{Dp}\right)$ Versus Annular Space.

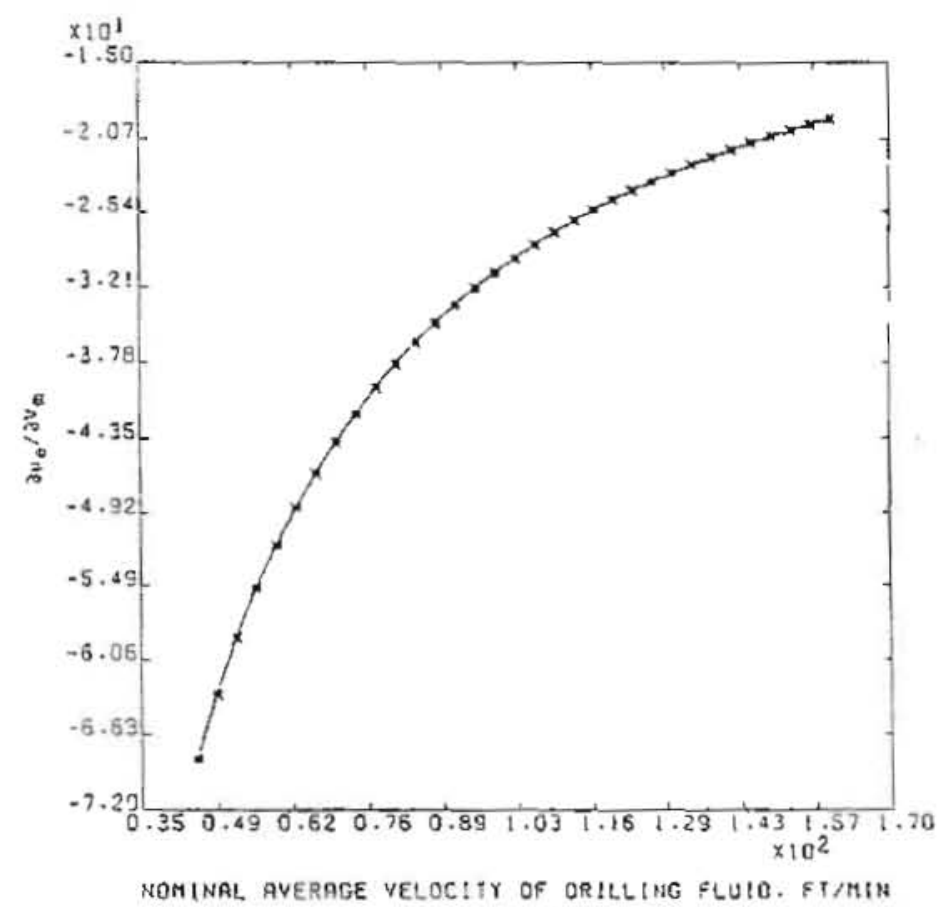

Fig. 4: $\partial \mathrm{ll}_{\mathrm{e}} / \hat{\partial} \mathrm{Vm}$ Versus Nominal A verage Veloctty of Orilling Fluid. 
Thus, Equ. (18) was verified using field data from the North Sea drilling region (10) that shown in Table (1). Also, an additional venfication was performed for Equ. (18) utilizing field data from field study 2 -wells $A, B$ and $C$ in the Nonth $S e a \mid 11]$ which are given in Table (2). The predictions of Equ. (18) using field data from Tables 1 \&. 2 are given in Tables 3 \& 4 , respectively.

Table 1 : The fieid data from Well X-North Sea Area [10] for the verification of Regression Approach " $\mu_{e} "$, Case I

\begin{tabular}{|c|c|c|c|c|c|c|c|}
\hline \multirow{3}{*}{$\begin{array}{c}\text { No } \\
\text {. }\end{array}$} & \multirow{3}{*}{$\begin{array}{c}\text { Variable Set } \\
\text { Abbreviation } \\
\text { MD. RKBft }\end{array}$} & \multicolumn{6}{|c|}{ Well X } \\
\hline & & \multicolumn{5}{|c|}{ Sec. $17.5^{\prime \prime}$} & \multirow{2}{*}{$\frac{\text { Sec. } 12.25^{\prime \prime}}{11759}$} \\
\hline & & 695 & $15 ! 2$ & 1654 & 3414 & 6261 & \\
\hline 2 & $D_{H^{-}}-D_{p}$, in. & 12.5 & 12.5 & 12.5 & 12.5 & 12.5 & 7.25 \\
\hline 3 & $\mathrm{Q}_{\mathrm{m}}, \mathrm{gpm}$ & 954 & 958 & 958 & 958 & 958 & 599 \\
\hline 4 & $\mu \mathrm{p}, \mathrm{cps}$ & 8 & 9 & 14 & 14 & 8 & 26 \\
\hline 5 & $Y_{p}, 1 b / 100 A^{2}$ & 40 & 16 & 20 & 49 & 40 & 24 \\
\hline 6 & $\mathrm{~V}_{\mathrm{m}}, \mathrm{f} / \mathrm{min}$ & 83.2 & 83.5 & 83.5 & 83.5 & 83.5 & 117.5 \\
\hline
\end{tabular}

Tabie 2. The field data from Wells A.B,C in North Sea Area [11] for the verification of Regression Approach " $\mu_{e}$ ", Case 2

\begin{tabular}{|c|c|c|c|c|c|c|}
\hline No. & Well & $\begin{array}{c}\mu \mathrm{p}, \\
\mathrm{cps}\end{array}$ & $\begin{array}{c}\mathrm{Y}_{\mathrm{p},} \\
\mathrm{tb} / 100 \mathrm{ft}^{2}\end{array}$ & $\begin{array}{c}\mathrm{Q}_{\mathrm{m},} \\
\mathrm{gpm}\end{array}$ & $\begin{array}{c}\mathrm{D}_{\mathrm{H}}, \\
\text { inches }\end{array}$ & $\begin{array}{c}\mathrm{Dp}_{\mathrm{p}} \\
\text { inches }\end{array}$ \\
\hline 1 & & $\mathrm{i}$ & 13 & 900 & 17.5 & 5 \\
2 & & 34 & 15 & 900 & 17.5 & 5 \\
3 & $\mathrm{~A}$ & 18 & 13 & 600 & 12.25 & 5 \\
4 & & 28 & 18 & 600 & 12.25 & 5 \\
5 & & 18 & 13 & 400 & 8.5 & 5 \\
6 & & 29 & 19 & 400 & 8.5 & 5 \\
\hline 1 & & 16 & 18 & 1100 & 17.5 & 5 \\
2 & & 30 & 30 & 1100 & 17.5 & 5 \\
3 & $\mathrm{~B}$ & 19 & 18 & 650 & 12.25 & 5 \\
4 & & 30 & 34 & 650 & 12.25 & 5 \\
5 & & 30 & 26 & 485 & 8.5 & 5 \\
6 & & 35 & 34 & 485 & 8.5 & 5 \\
\hline 1 & & 20 & 20 & 450 & 17.5 & 5 \\
2 & $\mathrm{C}$ & 30 & 33 & 550 & 17.5 & 5 \\
3 & & 30 & 25 & 550 & 12.25 & 5 \\
4 & & 45 & 30 & 550 & 12.25 & 5 \\
\hline
\end{tabular}


Table 3 : Comparison between Predictions of Regression Approach of Effective Annular Viscosity of Drilling Fluid and Predictions of Bingham Plastic Model of Etfective Annular Viscosity of that Fluid. Case $\mathrm{L}$.

\begin{tabular}{|c|c|c|c|c|}
\hline \multirow[b]{2}{*}{ No. } & $\mathrm{He}_{\mathrm{e}}(\mathrm{pr}), \mathrm{cps}$ & $\mu_{\varepsilon}$ (B), cps & Accuracy, \% & \multirow[b]{2}{*}{$\begin{array}{l}\text { Deviation Errors } \\
\begin{array}{c}=100 \text {-accuracy } \\
=\%\end{array}\end{array}$} \\
\hline & $\begin{array}{l}\text { Predictions of } \\
\text { Regression } \\
\text { Approach of } \\
\text { Effective Mud } \\
\text { Annular Viscosity }\end{array}$ & $\begin{array}{l}\text { Predictions of } \\
\text { Bingham Model } \\
\text { of Effective Mud } \\
\text { Annular } \\
\text { Viscosity }|3|\end{array}$ & $=\frac{\mu_{e}(p r)}{x 100} \frac{\mu_{e}(B)}{x}$ & \\
\hline 1 & 1735 & 1811 & 95.8 & +4.2 \\
\hline 2 & 691 & 727 & 95 & +5.0 \\
\hline 3 & 864 & 912 & 94.7 & +5.3 \\
\hline 4 & 2116 & 2214 & 95.6 & +4.4 \\
\hline 5 & 1727 & 1804 & 95.8 & +4.2 \\
\hline 6 & 560 & 597 & 93.8 & $\div 6.2$ \\
\hline
\end{tabular}

Table 4: Comparison between Predictions of Regression Approach of Effective Annular Viscosity of Drilling Fluid and Predictions of Bingham Plastic Model of Effective Annular Viscosity of that Fiuid, Case 2.

\begin{tabular}{|c|c|c|c|c|c|}
\hline & & $\mu_{c}(p r), c p s$ & $\mu_{s}$ (B), cps & Accuracy, $\%$ & \\
\hline $\begin{array}{c}\text { Wel } \\
1\end{array}$ & No. & $\begin{array}{l}\text { Predictions of } \\
\text { Regression } \\
\text { Approach of } \\
\text { Effective Mud } \\
\text { Annular Viscosity } \\
\end{array}$ & $\begin{array}{c}\text { Predictions of } \\
\text { Bingbam Model } \\
\text { of Effective Mud } \\
\text { Annular } \\
\text { Viscosity|3| }\end{array}$ & $=\frac{\mu_{\mathrm{e}}(\mathrm{pr})}{x \in 00}$ & $\begin{array}{c}\text { Deviation } \\
\text { Errors } \\
=100 \text {-accuracy } \\
=\%\end{array}$ \\
\hline A & $\begin{array}{l}1 \\
2 \\
3 \\
4 \\
5 \\
6\end{array}$ & $\begin{array}{l}598 \\
827 \\
231 \\
320 \\
633 \\
924\end{array}$ & $\begin{array}{c}636 \\
894 \\
258 \\
361 \\
838 \\
1251\end{array}$ & $\begin{array}{l}94.0 \\
92.5 \\
89.5 \\
88.7 \\
75.5 \\
73.9\end{array}$ & $\begin{array}{r}+6.00 \\
+7.50 \\
+10.5 \\
.7 \\
+24.5 \\
+26.1\end{array}$ \\
\hline B & $\begin{array}{l}1 \\
2 \\
3 \\
4 \\
5 \\
6\end{array}$ & $\begin{array}{l}677 \\
1128 \\
269 \\
558 \\
104 \\
136 \\
\end{array}$ & $\begin{array}{l}720 \\
1203 \\
326 \\
610 \\
139 \\
177\end{array}$ & $\begin{array}{l}94.0 \\
93.8 \\
90.6 \\
91.5 \\
75.4 \\
77.2 \\
\end{array}$ & $\begin{array}{l}+6.00 \\
+6.20 \\
\div 9.40 \\
+8.50 \\
+24.6 \\
+22.8\end{array}$ \\
\hline $\mathrm{C}$ & $\begin{array}{l}1 \\
2 \\
3 \\
4\end{array}$ & $\begin{array}{c}1839 \\
2482 \\
485 \\
582\end{array}$ & $\begin{array}{c}1931 \\
2610 \\
534 \\
650\end{array}$ & $\begin{array}{l}95.2 \\
95.1 \\
90.8 \\
89.5\end{array}$ & $\begin{array}{l}+4.800 \\
+4.900 \\
+9.20 \\
+10.5\end{array}$ \\
\hline
\end{tabular}


In the field, the Bingham plastic model is used to predict values for the effective annuiar viscosity of drilling fluid, this model is given as follows:

$$
\mu_{e}=\mu_{p}+300\left[\frac{\mathrm{Y}_{p}\left(\mathrm{D}_{H}-\mathrm{D}_{p}\right)}{\mathrm{V}_{m}}\right]
$$

where:

$$
V_{m}=\frac{Q_{m}}{\frac{\pi}{4}\left(D_{H}^{2}-D_{p}^{2}\right)}
$$

Detals of Equ. (24) is given in reference |3|. Applying the Bingham plastic model that is Equ. (24) and using field data from Tables 1 \& 2, the predictions of Bingham's model for the effective annular viscosity of the drilling fluid were obtained as shown in Tables $3 \& 4$. Table 3 shows the accuracy of prediction, using Equ. (18), the effective annular viscosity of the drilling fluid with respect to the Bingham model predictions model lie within the range of $93.8 \%$ to $95.8 \%$ with deviation error of $(+4.2 \%)$ to $(+6.2 \%)$. The average accuracy of the predictions of the equation for the effective annular viscosity of drilling flutd in the North Sea drilling regron is $95 \%$ with a deviation error of $(+5.0 \%)$.

Aiso, from Table (4), The accuracy of the preoictions with Equ. (18) for the effective annular viscosity of drilling fluid using field data from Table (2) ranges from $73.9 \%$ to $95.2 \%$ with deviation errors from $(\div 4.8 \%)$ to $(26.1 \%)$. However. the average accuracy of the predictions is $82 \%$ of a deviation error of $(-18.0 \%)$ based on $V_{m}$ the estimated nominal average velocity of the drilling fiuid. There are two averagc preaicted accuracies using Equ. (18) for the effective annular viscosity of the driling fluid at two different conditions. namely, using $V_{m}$ values from equation estumates values of $\mathrm{V}_{\mathrm{m}}$ and using estimated vaiues of $\mathrm{V}_{\mathrm{n}}$ obtained from mud pump thow rate. The two accuracies are $95.0 \%$ as shown in Table (3) and $82.0 \%$ as shown in Table (4). Finally. Equ. (1\$) or regression approach is called as the "regression model" i.e. simular to Bingham plastic model. Polynomial model, and Power-law model to predict the values for thic effective annular viscosity of drilling fluid.

\section{APPLICATION OF REGRESSION APPROACH OF " $\mu_{e} "$ "IN OILWELL DRILLING INDUSTRY}

The most important application of this approach in oil-well drilling industry is to evaluate the lifting capacity of drslling fluid, i.e. drilled-cuttings transport or annular hole cleaning. This effective annular viscosity of drilling fluid which can be calculated by the regression approach is related directly to the rate of drilled-cuttings will slip through the drilling fluid in the annulus ol: well-bore.

$$
V_{1}=\frac{4973 d_{c}^{2}\left(\rho_{s}-\rho_{m}\right)}{\mu_{s}}
$$

Also. the net upivard rise velocity of drilled-cuttings, $V_{c}$, can be calculated as follows: 


$$
\mathrm{v}_{\mathrm{c}}=\mathrm{v}_{\mathrm{m}} \cdot \mathrm{v}_{\mathrm{s}}
$$

Slip velocity of drilled-cultings can be analyzed into the axial and radial components during drilling the deviated or inclined we!l-bore section from the kick-off point (KOP) to the end of pay zone in directıonal wells. these components are:

$$
\begin{aligned}
& \text { Axial component of slip veiocity }=\mathrm{V}_{\mathrm{sa}}=\mathrm{V}_{\mathrm{S}} \operatorname{Cos} \theta \\
& \text { Rôdia! component of slip velocity }=\mathrm{V}_{\mathrm{Sr}}=\mathrm{V}_{\mathrm{S}} \operatorname{Sin} \theta
\end{aligned}
$$

Thus.

$$
\mathrm{v}_{\mathrm{c} \min }=\mathrm{v}_{\mathrm{m} \min }-\mathrm{v}_{\mathrm{s} \text { i }}
$$

Where $V_{c} \min$ is the minimum net upward nse or transport velocity of drilleci-cuttings in the eccentric annulus of directional well during drilling. The net upward rise or transpon velocity of drilled-cuttings may affect the concentration of annular drilled-cuttings.

\section{CONCLUSIONS}

The foilowing are the conclusions which are drawn from this research:

1. The physical situation of predicting the effective viscosity of drilling fluid in the annulus of weil-bore during trilling, is a complicated engineering probiem but can be described by simpie equation linking the dependent and independent parameters which are related and alfect the real system.

2. Regression, non-linear. muiti-dimensional. dimensionless. effective annular mud viscosity approach for ofl well drilling applications was developed.

3. This approaci was evaluated parametrically to measure the effect on the approach of clianging one of the independent parameters with respect to the dependent parameter, that is referred to as sensitivity analysis or parametric study. From this parametric study. u was found that the effective annulat viscosity of drilling fluid increases as the following parameters increase:

i. The yield point of the drilling fluid.

ii. The plastic viscosity of the drilling fluid.

iii. The annular space between the drill-pipe and the wall of the hoie.

Also, the effective annular viscosity of drilling fluid decreases as the designed nominal average velocity of the drilling fluid increases.

4. The regression approach is a practical technique to accurately predict the effective viscosity of dritling fluid in the annulus of well-bore during rotary drilling process. These predicted values of the effective nud viscosity are useful for the following parameters that affect the hole cleaning. i.e. drilled-cuttings transport process. that are:

i. Absolute slip velocity of driiled-cuttings for vertical dralling process of oil wells.

ii. Axial and radial components of slip velocity of drilled-cuttings for directional and horizontai drillıng processes of oil wells, taking into consideration that the axial component of stip velocity in horizontai drilling process is equat to zero.

iii.The net upward rise or transport velocity of drilled-curtings affects the value of annular concentration drilled-cuttings. 
5. The regression approach was verified and compared with existing models such as Bingham plastic model. The approach's predictions for the effecuve annular viscosity of dniling fluid were close with the results obtained from the Bingham piastic model in most cases. Thus, it is considered this regression approach as the fourth model sinnilar to Power-law model, Bingham plastic model and Poiynomial model. Accordingly, it was found that the regression approach's predictions were more realistic and reasonable which show a significant virtne that could be used by the onl well drilling industry.

\section{RECOMMENDATIONS}

The following are the recommendations for the future work:

I It is reconumended that the developed regression approach should be tested practicalty in actual rotary driling operations to determine the precision of its predictions under operarional drilling conditions.

2. It is recommended that the developed regression approaci's predictions should be compared whth the resuits obtained from the Power-law model and the Polynonial modiel to determine its predictions under operational drilling conditions.

3. This approach can be used for the design of adequate hole cleaning progran during rotary drilling process of oil wells, so as to obtain the higher drilling rate at the lowest driling cost. in other words, this developed regression approach offers real scope for applying drilling optimization technique. In tur), optimum drilling operations design could be obtained for adequate hole cleaning, in order to increase the drilling rate at the lowest possible drilling cost. Therefore, there are several aspects which could be considered. to develop the present approach to take part for drilling optımization applicatıons, these operating conditions or aspecis including:

i. Mud properties in terns of theological properties which are:

1. Plastic viscosity.

2. Yield point or ratio of yieid point to plastic viscosity.

ii. Mud hydraulics in terms of nominal average velocity of driling fluid th the anulus which is supported by the desıgned mud flow rate.

4. It is recommended that a mud with "inverted rheology" characteristics (higher ratio of yield. point to plastic viscosity of that mud) such as inverted-oil-emulsion mud should be used for drilling pay zones in vertical oil wells, and it is also used during drilling directional and horizontal oil wells. Thus, this approach could be used to plan the mud program for inverted rheology characteristics.

\section{NOMENCLATURE}

Aa $=$ cross sectional area, in ${ }^{2}$.

A. B, C. E, $m$ = fluid model constants.

c = unknown constant added by dimensional analysis technique.

$\cos =$ cosine $\quad$ Sin $=$ sine

$D_{\mathrm{HI}} \quad=$ hole diameter. inches.

Dp = outside diameter of drill-pıpe, inches.

Equ. = Equation.

$\mathrm{d}_{\mathrm{c}} \quad=$ equivalent drilled-cutting size or diameter, inches.

f $\quad=$ inathematical function. 


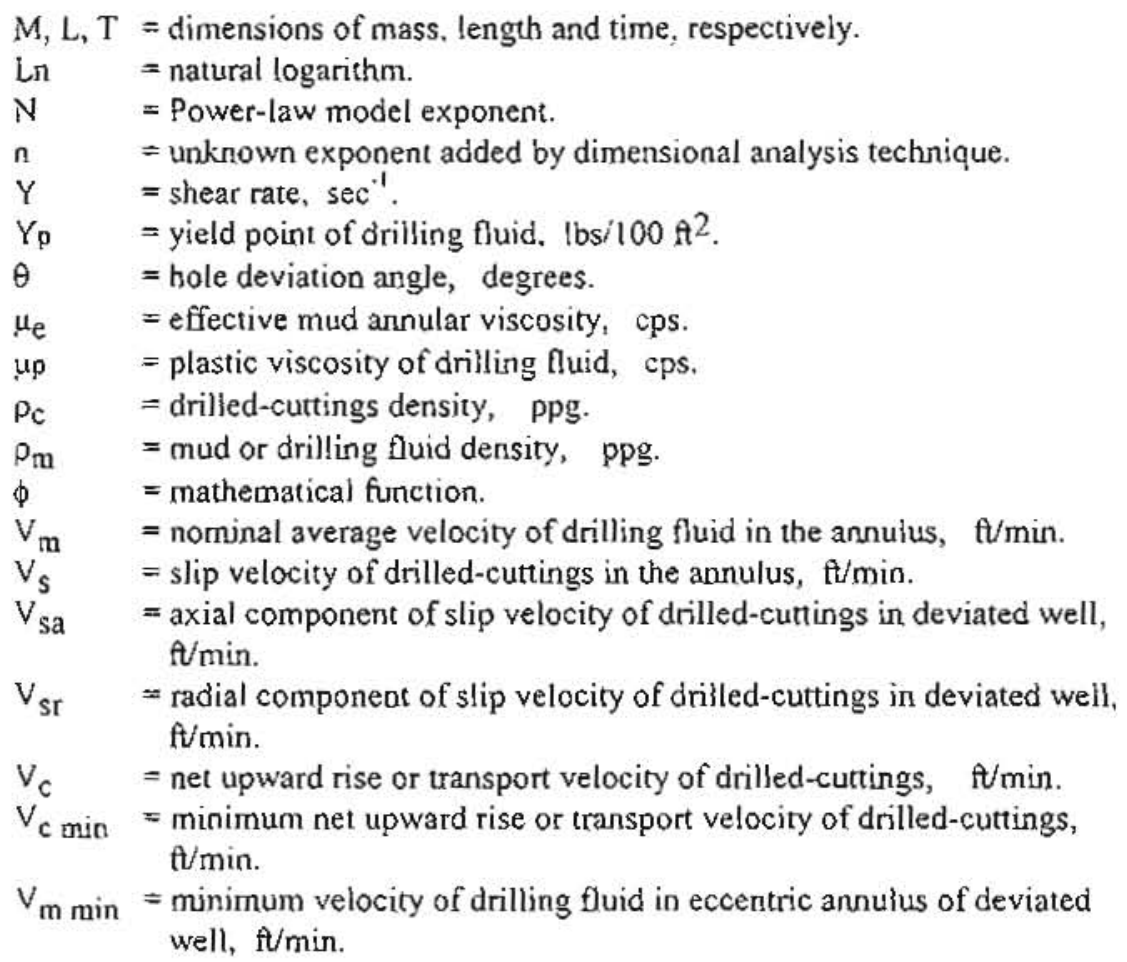

\section{REFERENCES}

1. Waiker, R.E.: "How to Predict Mud Performance", the Oil and Gas Joumal, March 30, 1964. $65-70$.

2. Wanneng, S., Jianping, C. and Zhenxe, L.: "Comparison of Rheological Models in High Shear Rate Range and Experimental Relationship between Penetration Rate and High Shear Viscosities", SPE No. 14858 paper was presented at the SPE 1986 International Meeting on Petroleum Engineering held in Beijing, China, March 17-20.

3. Rabia. H.: Oil-Well Drilling Engineering: Principles and Practice' Graham and Trotman Publishing Co., 1985, Chapter 5.

4. Willis. H.G., Tomm. W.R. and Forbes, E.E.: "Annular Flow Dynamics", SPE No. 4234 paper presented at the Sixth Conference on Drilling and Rock Mechanics, the Society of Petroleum Engineers of AIMIE, held in Austin, TX., Jan. 22-23, 1973.

5. Sharp, G.J.: Fluid Flow Analysis, Chapter 1, Heineman, Educational Books Ltd., London, 1967.

6. Froken, C.M.: Dimensional Methods and their Applications, Edward Amold Co., London, 1953.

7. Ryan, T.A., Joiner, B.L. and Ryan, B.F.: Minitab Student Handbook, Duxbury, Boston, U.S.A., 1982.

8. Ryan, T.A., Joiner, B.L. and Ryan, B.F.: Minitab Reference Manual, Duxbury, Boston, U.S.A., 1982. 
M. 91 Or. M.S. Farahat

9. Fugazi, K.: CSMP Continuous System Modeling Program for the B6700, Devis Computer Center. University of Califomia, August 1973.

10. Farahat. M.S.: A Project of Cuttings Transport in Deviated Wells, Pet. Eng. Dept., Faculty of Engineering, Heriot-Watt University, Edinburgh, 1985-1988.

11. Holder. B.J.: "Drilling Fluids for Highly Deviated Weils in North Sea Petroleum Drilling", JPT, April 1982, pp. 703-712. 